\title{
The change of tide in political cooperation: a limited information model of European integration
}

Gerald Schneider and Lars-Erik Cederman

In the mid-1970s, Prime Minister Harold Wilson refused to commit Britain to European Community (EC) membership during the renegotiations about entry terms for the United Kingdom. ${ }^{1}$ Perceiving this position as a "possible threat with a British exit," German Chancellor Helmut Schmidt did not downplay the credibility of the British bargaining strategy but rather conceded to Wilson's demands. Instead of bringing the lone maverick into line, the majority reached an accord with Britain which, in Schmidt's words, was "by no means cheap for Germany."3

This agreement is but one of several cases in which the EC has been blackmailed by one of its members yet managed to overcome the crisis. Although the community never experienced the permanent exit of one of its members, strategies of noncommitment significantly have affected the course of European integration, yielding a process characterized by dramatic shifts. The stop-and-go pattern of high-level interaction has haunted the EC since its founding. In the early 1980s the consequent inertia in the EC and its main member countries was described as "Eurosclerosis."

This article is a revised version of a paper presented at the 1992 annual meeting of the American Political Science Association, Chicago, 3-6 September 1992; and the Inaugural Pan-European Conference of the European Consortium for Political Research Standing Group on International Relations, Heidelberg, Germany, 16-20 September 1992. We would like to thank Chris Achen, Douglas Dion, Gary Goertz, John Huber, Michael Nicholson, John Odell, Robert Pahre, George Tsebelis, the reviewers of this journal, and especially Simon Hug, Cheryl Shanks, and Patricia Weitsman for their helpful comments. The authors gratefully acknowledge financial support received from the Swiss National Science Foundation (grant 8210-030615) and the Social Science Research Council/MacArthur Foundation.

1. This article refers to the history of the EC. However, because the Treaty on European Union (Maastricht treaty) did not change the logic of the stop-and-go process, our analysis is also valid for its successor organization, the European Union (EU).

2. Helmut Schmidt, Die Deutschen und ihre Nachbarn (The Germans and their neighbors) (Berlin: Siedler, 1990), p. 96.

3. Ibid., p. 97.

4. Horst Siebert, The New Economic Landscape in Europe (Oxford: Basil Blackwell, 1991), p. 1.

International Organization 48, 4, Autumn 1994, pp. 633-62

(C) 1994 by The IO Foundation and the Massachusetts Institute of Technology 
The predominant theories of international politics address only one side of the process described above. They emphasize either the failures or the successes of integration processes but generally fail to provide a comprehensive explanation of both tendencies simultaneously. ${ }^{5}$ To account for both the "stop" and the "go" in regional integration, researchers have to reconcile neorealist pessimism with liberal optimism. Some authors recently suggested that compromises between the two paradigms are possible and desirable. ${ }^{6}$ In this article, we take a step in the direction of closing this explanatory gap. We argue that contemporary neorealist and liberal theories pay insufficient attention to the strategic use of uncertainty in international negotiations. The example above suggests that European leaders have not shied away from using threats and other coercive bargaining tactics and that such tactics can have momentous consequences for the dynamics of integration.

While uncertainty plays a prominent role in both neorealist and liberal accounts of international cooperation, it has usually been invoked to bolster the explanations scholars already have committed themselves to. For example, Kenneth Waltz and Robert Jervis each argue that the fundamental uncertainty of international anarchy forces states to refrain from integrationist moves. ${ }^{7} \mathrm{On}$ the other hand, neoliberal institutionalists, such as Robert Keohane, have highlighted the facilitating effect of international regimes on information flows and how this helps to promote interstate cooperation. ${ }^{8}$ Although these structural arguments are undoubtedly crucial to a proper understanding of international politics, they fail to address the micro-level of diplomatic negotiations. This article attempts to build a bridge between the neorealist and liberal arguments by exploiting recent advances in information economics. ${ }^{9}$

5. See for instance Andrew Moravcsik, "Negotiating the Single European Act: National Interests and Conventional Statecraft in the European Community," in Robert O. Keohane and Stanley Hoffmann, eds., The New European Community, Decisionmaking and Institutional Change (Boulder, Colo.: Westview, 1991), pp. 41-84; Wayne Sandholtz and John Zysman, "1992: Recasting the European Bargain," World Politics 42 (October 1989), pp. 95-128; and Geoffrey Garrett, "International Cooperation and Institutional Choice: The European Community's Internal Market," International Organization 46 (Spring 1992), pp. 533-60.

6. Emerson M. S. Niou and Peter C. Ordeshook make this point in " 'Less Filling, Tastes Great': The Realist-Neoliberal Debate," World Politics 46 (January 1994), pp. 209-34. For similar statements see Andrew Moravcsik, "Liberalism and International Relations Theory," The Center for International Affairs working paper no. 92-6, Harvard University; Joseph Nye, "Neorealism and Neoliberalism," World Politics 40 (January 1988), pp. 235-51.

7. See Kenneth N. Waltz, Theory of International Politics (Reading, Mass.: Addison-Wesley, 1979); and Robert Jervis, "Cooperation Under the Security Dilemma," World Politics 30 (January 1978), pp. 167-214.

8. Robert O. Keohane, After Hegemony: Cooperation and Discord in the World Political Economy (Princeton, N.J.: Princeton University Press, 1984).

9. Spence's pioneering work on uncertainty in labor markets laid the foundation for this type of modeling; see Michael Spence, Market Signaling (Cambridge, Mass.: Harvard University Press, 1974). Recent advances in noncooperative game theory introduced powerful tools to study signaling in social situations. For a technical introduction, see Jeffrey Banks, Signaling Games in Political Science (Chur, Switzerland: Harwood Academic Publishers, 1991). In political science, such models have been most successfully applied to legislative bargaining and deterrence theory. For a comprehensive analysis of the former, see Keith Krehbiel, Information and Legislative 
These models show how uncertainty may influence the bargaining outcome. Typically, some actors, assumed to possess "private information," exploit this asymmetry in order to obtain a favorable solution. This gives "weak" actors an incentive to mimic their stronger counterparts. Such bluffs force strong types to distinguish themselves by issuing costly signals that may ultimately lead to suboptimal outcomes. ${ }^{10}$

In accordance with functionalist theories, our models assume that all actors prefer some degree of further integration. However, unlike the liberal paradigm, we study the effects of disagreements concerning the precise level of cooperation. In particular, we examine situations involving an "integrationist" government or coalition of governments and a "laggard" state. This obstructionist member is also interested in deepening formal cooperation but prefers a more modest outcome to the ambitious option preferred by the integrationist side. The formal framework demonstrates that, even under liberal assumptions, strategic manipulation under uncertainty might lead to neorealist outcomes such as the breakdown of negotiations. The integration process can reach an impasse after the laggard's use of threats. Such manipulations become possible because of private information about the cost of exiting the organization (the "exit game"), about the ratification process (the "ratification game"), or about the likelihood of the obstructionist government losing domestic power to a less integration-friendly opposition (the "takeover game"). Our results highlight the importance of uncertainty in such situations. Under complete information, functionalist predictions are upheld: the integration process proceeds, although the precise level of integration depends on the credibility of the laggard's threat. If information is more unevenly spread, however, stalemate may follow despite all governments' wish to find an agreement.

We do not argue that these three models elucidate all aspects of integration negotiations. The analysis pertains to the summit negotiations of the European Council. ${ }^{11}$ Nor do we claim that strategic uncertainty exhausts the sources of incomplete knowledge in international politics. ${ }^{12}$ Yet, our rational choice approach captures the counterintuitive effects of information asymmetries and puts the study of international bargaining on a more solid analytic footing. It

Organization (Ann Arbor: University of Michigan Press, 1991) on the latter, see Robert Powell, Nuclear Deterrence Theory (Cambridge: Cambridge University Press, 1990).

10. See for instance James D. Fearon, "Deterrence and the Spiral Model: The Role of Costly Signals in Crisis Bargaining," paper presented at the annual meeting of the American Political Science Association, San Francisco, 30 August-2 September 1990.

11. Though this article is specifically addressed to European Council summits, our theory is potentially useful for other types of summit meetings, such as those analyzed by Robert D. Putnam and Nicholas Bayne, Hanging Together: Cooperation and Conflict in the Seven-Power Summits, rev. ed. (Cambridge, Mass.: Harvard University Press, 1987).

12. For the analysis of "analytic uncertainty," see Keisuke Iida, "Analytic Uncertainty and International Cooperation: Theory and Application to International Economic Policy Coordination," International Studies Quarterly 37 (December 1993), pp. 431-57. 
helps to overcome the tendency in regional integration research to bias examinations in favor of breakthroughs or deadlock situations. ${ }^{13}$

The article is organized as follows: the next section presents the puzzle of this article, the stops and starts in European cooperation. The third section discusses possible analytic solutions to the stop-and-go problem in regional integration. Our three models are presented in the fourth section. Finally, the conclusion sums up the findings and points to avenues of future research. Technical details can be found in the appendix.

\section{Stops and starts in the history of European integration}

EC integration proceedings have oscillated between short-lived euphoria and agonizingly protracted stalemates. Institutional development has thus been rather unpredictable. Since stalemates historically have been largely a consequence of disagreement over the level of cooperation, we will focus on conflicts that have arisen during crucial summits of the organization. Our limited information models show that the manipulation of uncertainty during the summit meetings of the European Council is a major cause of the stop-and-go logic of the integration process. The European Council as the "board of directors" 14 for the overall organization has become so important that Simon Bulmer and Wolfgang Wessels describe the development of the EC in the 1970 s and 1980s as the history of the council summits. ${ }^{15}$ Even before the establishment of the European Council in 1975, no major agreement was possible without the consent of all members. ${ }^{16}$ Consequently, an institutional equivalent to the council has existed since the creation of the EC. ${ }^{17}$

The structure of the summit meetings enables the laggard state to blackmail the other members. Threats are possible as long as the integrationist side prefers a solution including the laggard over an agreement that excludes the obstructionist member. We assume that the bargaining space at the crucial summit meetings is unidimensional and consists of two possible treaties,

13. This argument is in line with Christopher H. Achen and Duncan Snidal, "Rational Deterrence Theory and Comparative Case Study," World Politics 41 (January 1989), pp. 43-69.

14. Stephen George, Politics and Policy in the European Community (Oxford: Clarendon Press, 1985), p. 13.

15. Simon Bulmer and Wolfgang Wessels, The European Council: Decision-making in European Politics (London: Macmillan, 1987), p. 2. This is the most informative study of the European Council from a literature that is mainly descriptive. For the impressionistic observations of two civil servants who participated in several summits, see Michael Butler, Europe: More than a Continent (London: Heinemann, 1986); and Marcell von Donat, Das ist der Gipfel! Die EG-Regierungschefs unter sich (This is the summit! The EC heads of government among themselves) (Baden-Baden, Germany: Nomos, 1987).

16. The European Council was formally established by a declaration at the 1974 Paris summit meeting.

17. Few procedures other than meeting twice a year govern the unanimously ruled council meetings. Until 1985, the European Council met three times a year. At special occasions, the council convenes at short notice (e.g., after the breakdown of the Berlin Wall). For a description see Butler, Europe, p. 80. 
implying either "more" or "less" integration. ${ }^{18}$ The difference between the two agreements is qualitative, representing the absence or presence of an important indivisible integration feature such as the creation of a common currency. Compromises between the modest option (the "Less treaty") and its integrationist alternative (dubbed the "More treaty") are excluded because of the actors' domestic commitment to their preferred position prior to the negotiations. While the laggard declares a preference for the Less treaty over the More treaty, the integrationist government opts for the More treaty.

The maverick can launch three different threats to preserve sovereignty: first, it can threaten to leave the organization (full exit threat) or some area of cooperation (partial exit threat). Second, the laggard may claim that its domestic constituents will reject the treaty unless the modest integration project is adopted (ratification threat). Third, obstructionist governments are able to exploit the possibility of a takeover by an allegedly less integrationminded opposition (takeover threat). The integrationist can counter these demands by threatening to move ahead without the constrained government (exclusion threat).

Because of such manipulations the summit negotiations of the European Council can produce different outcomes. While the Less and More treaties represent different levels of deepening formal cooperation, the issue of widening (or narrowing) also enters the calculations. ${ }^{19}$ Implementation of an exit threat would result in an integration failure implying deepening at the expense of narrowing integration. If the threat concerns a full exit, integration failure results in the formal withdrawal of one member state. "Partial integration failures" happen if the integrationist majority pushes ahead by signing the More treaty despite the refusal of the laggard to accept the entire treaty. In this case, the latter state is granted an exception from the contested legislation. Though it is possible that the laggard will later sign the full treaty, this arrangement threatens to create a Europe à deux vitesses (two-tier Europe).

When the other members believe that a threat by the obstructionist state is credible, the Less treaty is accepted. This implies the adoption of modest progress or the preservation of the status quo in the event that the laggard is not interested in deepening the formal cooperation. The manipulation of uncertainty may also lead to an integration breakthrough because the ambitious governments can point to the laggard's incredibility and force the obstructionist member to give in to their far-reaching project.

18. The assumption of unidimensionality is justified as long as no side-payment is large enough to appease the laggard. In other words, issue linkage is possible for minor decisions. Such multidimensional problems are discussed in Leon Lindberg, "Political Integration as a Multidimensional Phenomenon," International Organization 24 (Autumn 1970), pp. 694-731.

19. On widening versus deepening see Helen Wallace, "Widening and Deepening: The European Community and the New European Agenda," Royal Institute for International Affairs (RIIA) discussion paper no. 23, RIAA, London, 1989; and Anna Michalski and Helen Wallace, The European Community: The Challenge of Enlargement (London: Royal Institute of International Affairs, 1992). 
TABLE 1. Crucial stop-and-go events in the history of the European Community (EC)

\begin{tabular}{|c|c|c|c|c|c|}
\hline Year & Laggard & Less treaty & More treaty & $\begin{array}{l}\text { Laggard's } \\
\text { threat }\end{array}$ & Outcome \\
\hline $1963 / 68$ & France & $\begin{array}{l}\text { No enlargement } \\
\text { of the EC }\end{array}$ & $\begin{array}{l}\text { Enlargement of } \\
\text { the EC }\end{array}$ & Full exit & $\begin{array}{l}\text { Stalemate } \\
\text { (Less treaty) }\end{array}$ \\
\hline 1965 & France & $\begin{array}{l}\text { Preservation of } \\
\text { veto right }\end{array}$ & $\begin{array}{l}\text { Empowerment of } \\
\text { commission }\end{array}$ & Full exit & $\begin{array}{l}\text { Stalemate } \\
\quad \text { (Less treaty) }\end{array}$ \\
\hline 1975 & Britain & Renegotiations & $\begin{array}{l}\text { Acceptance of } \\
\text { original treaty }\end{array}$ & $\begin{array}{l}\text { Exit/ } \\
\quad \text { ratification }\end{array}$ & $\begin{array}{l}\text { Stalemate } \\
\quad \text { (Less treaty) }\end{array}$ \\
\hline 1978 & Britain & $\begin{array}{l}\text { No European } \\
\text { Monetary System }\end{array}$ & $\begin{array}{l}\text { European Monetary } \\
\text { System }\end{array}$ & Partial exit & $\begin{array}{l}\text { Breakthrough with } \\
\text { partial exit }\end{array}$ \\
\hline 1979-84 & Britain & $\begin{array}{l}\text { Renegotiations on } \\
\text { budget }\end{array}$ & $\begin{array}{l}\text { No renegotiations } \\
\text { on budget }\end{array}$ & Full exit & $\begin{array}{l}\text { Stalemate } \\
\text { (Less treaty) }\end{array}$ \\
\hline 1984 & Britain & $\begin{array}{l}\text { Only Internal } \\
\text { Market }\end{array}$ & $\begin{array}{l}\text { Single European } \\
\text { Act and Internal } \\
\text { Market }\end{array}$ & Partial exit & Breakthrough \\
\hline 1991 & Britain & $\begin{array}{l}\text { No European } \\
\text { social policy }\end{array}$ & $\begin{array}{c}\text { Social policy part } \\
\text { of Maastricht }\end{array}$ & Takeover & $\begin{array}{l}\text { Breakthrough with } \\
\text { partial exit }\end{array}$ \\
\hline 1992 & Denmark & $\begin{array}{l}\text { Maastricht with } \\
\text { opt outs }\end{array}$ & $\begin{array}{l}\text { Maastricht without } \\
\text { opt outs }\end{array}$ & Ratification & $\begin{array}{l}\text { Modest progress } \\
\text { (Less treaty) }\end{array}$ \\
\hline
\end{tabular}

Since no member country ever formally left the EC, it may seem that threats have played no important role in the history of the organization. Nonetheless, there is ample evidence to the contrary. ${ }^{20}$ Table 1 offers a nonexhaustive list of the most important changes in the process of European integration. ${ }^{21}$ Our analysis identifies the laggard and the year during which the threat was issued. Further, the table identifies the two main options at stake, the nature of the threat and the negotiation outcome.

The most famous instance of an exit threat is the "empty chair" episode. To block an institutional reform proposed by the European Commission, French

20. In international organizations other than the European Union, there are important cases where the exit threat was executed (e.g., France's exit from the North Atlantic Treaty Organization's military activities and the walkout by Britain and the United States from specialized agencies of the United Nations such as the United Nations Educational Scientific and Cultural Organization). In his pathbreaking study, Hirschmann refers to several examples of exit from economic organizations in the United States. See Albert O. Hirschmann, Exit, Voice and Loyalty (Cambridge, Mass.: Harvard University Press, 1970), pp. 27-29.

21. The selected cases also refer to situations where the laggard did not favor an increase in integration. Our models, however, exclude this contradiction to the liberal explanation. This means that our results are biased in favor of the optimist account of European integration. Early studies analyze some of the same events. Lindberg and Scheingold develop a "fever chart" to describe the ups and downs in the institutional development of the organization; see Leon N. Lindberg and Stuart A. Scheingold, Europe's Would-be Polity: Patterns of Change in the European Community (Englewood Cliffs, N.J.: Prentice Hall, 1971), p. 104. For an early ad hoc model explaining both integrative and disintegrative moves, see Joseph Nye, Peace in Parts (Boston: Little, Brown, 1971), chap. 3 . 
President Charles de Gaulle withdrew from participation in EC intergovernmental decision making from July to December 1965 . This maneuver contributed to the other governments' accepting the Luxembourg compromise, which perpetuated the practice of unanimous voting for crucial decisions. In 1963 and 1968, de Gaulle employed the same tactic when he single-handedly kept Britain out of the organization.

Some progress was made in the early 1970 s with the entry of Denmark, Ireland, and Britain. This enlargement, however, provoked another crisis stemming from blackmailing by a laggard member. We have already described how British Prime Minister Wilson successfully applied an exit threat during the renegotiations of entry terms for the United Kingdom in the mid-1970s. This strategy was not successful during the negotiations over the establishment of the European Monetary System (EMS) in 1978. France and Germany used the countermove of threatening to exclude Britain completely from the new regime. The laggard's position was influenced by fear that the loss of sovereignty implied by participation in the EMS would lead to a considerable devaluation of the British pound. ${ }^{22}$

Margaret Thatcher's ascension to power in Britain was concomitant with seemingly endless struggle about the EC budget. At the Dublin summit meeting in December 1979, the new British Prime Minister asked for a substantial reduction of Britain's contribution. To make her demands more convincing, she refused to agree upon a future meeting. The European Council could not resolve the dispute, and Prime Minister Thatcher did not concede to another summit "until literally the last five minutes," according to Chancellor Schmidt. ${ }^{23}$ The status quo dominated in the early 1980s, succeeding from Prime Minister Thatcher's continued insistence on getting "our money back." 24

The EC was revitalized by the Internal Market Program and the Single European Act (SEA) as well as with the adhesion of Portugal and Spain. After Prime Minister Thatcher had attained a more favorable settlement for the British contribution to the $\mathrm{EC}$, her threats became progressively less credible. As Andrew Moravcsik convincingly points out, this strategy was not compelling in the negotiations over the SEA. ${ }^{25}$ Thatcher had to retreat from her opposition to majority voting in internal market affairs because France and Germany used the threat of excluding the United Kingdom from the treaty. The weakening of veto power in the Council of Ministers was the most important consequence of the SEA. The British insistence on less integration also failed during the negotiations on the Treaty on European Union. Prime Minister John Major tried to raise the fear of a takeover by an anti-integrationist faction within the Conservative Party. However, he could only opt out partially from a most

22. Schmidt, Die Deutschen und ihre Nachbarn, p. 145.

23. Helmut Schmidt is quoted in Hugo Young, One of us (London: Macmillan, 1989), p. 187.

24. The phrase is Thatcher's; see Butler, Europe, p. 95.

25. Moravcsik, "Negotiating the Single European Act," p. 68. 
significant ingredient of this last breakthrough: the implementation of a European social policy. ${ }^{26}$

The unexpected rejection of the Maastricht agreement by Denmark in 1992 spawned the most recent period of stagnation. The initial rejection of the Treaty on European Union made the bargaining position of the Danish government very strong. In the renegotiations, the EC granted some major exceptions to its Scandinavian member to assure that the population would vote yes in the second attempt. This example shows that even a small laggard can successfully threaten the rest of the organization.

\section{Explaining the stop-and-go pattern in European integration}

In spite of the rocky history of European integration, most studies focus on either the achievements or setbacks of this process. The two dominating paradigms in international relations, neorealism and liberalism, cannot account for the "stop" and the "go" portions simultaneously. On the contrary, they claim that only one of these outcomes is possible. Neorealists believe that political integration is not feasible because of diverging state interests. Waltz used the relative gains argument to show why cooperation between states is so infrequent: "A state worries about a division of possible gains that may favor others more than itself." ${ }^{27}$ Structural realism predicts that the anarchical character of the international system and the resulting "self-help system" will inhibit any attempt to strengthen the ties between nations. Stalemate and even conflict would thus be the dominant features of European interactions.

This "impossibility hypothesis" lies in sharp contrast to the predictions of liberalism, which has been the more influential paradigm in integration research. Especially its neofunctionalist strand continues to shape the field sixty years after the publication of David Mitrany's The Progress of International Government. ${ }^{28}$ This persistence is evident in frequent allusions to "spillover effects," "supranationalism," and other traditional concepts. According to the general argument of functionalism, the presence of a systemic attribute (explanandum) can be explained in terms of its beneficial consequences (explanans) for the system. ${ }^{29}$ While functionalist reasoning has played an important role in sociological and anthropological theory, this trend has not escaped criticism. ${ }^{30}$ Typically, objections address the static character and

26. Richard Corbett, "The Intergovernmental Conference on Political Union," Joumal of Common Market Studies 30 (September 1993), pp. 271-98.

27. Waltz, Theory of International Politics, p. 106.

28. David Mitrany, The Progress of International Government (New Haven, Conn.: Yale University Press, 1933).

29. David Little, Varieties of Social Explanation: An Introduction to the Philosophy of Social Science (Boulder, Colo.: Westview, 1991), chap. 5.

30. For examples of classical sociological theory, see Talcott Parsons, The Structure of Social Action (New York: McGraw-Hill, 1937) and The Social System (Glencoe, Ill.: Free Press, 1951); and Robert K. Merton, Social Theory and Social Structure (New York: Free Press, 1963). For a sophisticated extension within the Parsonian tradition, see Niklas Luhmann, Soziale Systeme: 
collectivist perspective of functionalist theories ${ }^{31}$ or their lack of a convincing evolutionary mechanism. ${ }^{32}$

In international relations, functionalist arguments have been employed to explain cooperative behavior. The approach suggests that states participate in international governmental organizations mainly because of technological advances and the steadily growing demands of their constituents to improve the standard of living. ${ }^{33}$ Borrowing from liberal trade theory, functionalism sees integration as a "demand-driven" outflow of social pressures. This interpretation is also manifest in Ernst Haas's theoretical elaboration. ${ }^{34}$ In that approach, regional integration necessarily progresses under the condition that states prefer to intensify their cooperation; "if the actors, on the basis of their interest-inspired perceptions, desire to adapt integration lessons learned in one context to a new situation, the lesson will be generalized." 35 In other words, integration evolves gradually, with the cooperation spilling over from one decision-making function to another. ${ }^{36}$

Studies of regional integration rely on both neorealist and liberal approaches. Empirically, the ups and downs of the European integration process sharply contradict the two competing accounts of whether or not interstate cooperation is possible. According to neorealism, successful integration is hardly likely in the long run. Most critics agree that the liberal approach fails to explain why the intensification of political integration proceeds in a discontinuous manner despite converging interests. ${ }^{37}$ De Gaulle's ability to reinvigorate

Grundriss einer Allgemeinen Theorie (Social systems: Ground plan of a general theory), (Frankfurt am Main: Suhrkamp, 1984). See also Paul Colomy, ed., Functionalist Sociology: Classic Statements (Cheltenham: Edward Elgar, 1990); and Paul Colomy, ed., Neofunctionalist Sociology: Contemporary Statement (Cheltenham: Edward Elgar, 1990).

31. John Harsanyi, "Rational Choice Models of Political Behavior Versus Functionalist and Conformist Theories," World Politics 21 (July 1969), pp. 513-38.

32. Jon Elster, Explaining Technical Change (Cambridge: Cambridge University Press, 1983). Little aptly summarizes these objections: "Functional explanations are suspect in social science. ... In particular, they must be supplemented by detailed accounts of the social processes through which the needs of social and economic systems influence other social processes to elicit responses that satisfy those needs." See Little, Varieties of Social Explanations, p. 102.

33. Compare Harold K. Jacobson, William M. Reisinger, and Todd Mathers, "National Entanglements in International Governmental Organizations," American Political Science Review 80 (March 1986), p. 142. See also the discussion of economic process explanations in Robert O. Keohane and Joseph S. Nye, Power and Interdependence: World Politics in Transition (Boston: Little, Brown, 1977), pp. 38-42.

34. See Ernst B. Haas, The Uniting of Europe: Political, Social, and Economical Forces 1950-1957 (London: Stevens and Sons, 1958); and Ernst B. Haas, Beyond the Nation-State: Functionalism and International Organization (Stanford, Calif.: Stanford University Press, 1964).

35. Haas, Beyond the Nation-State, p. 48; italics original.

36. Quasi-functionalist thinking is nowadays present in some strands of neoinstitutional economics. For a discussion, see Jack Knight, Institutions and Social Conflict (Cambridge, Mass.: Cambridge University Press, 1992), p. 40.

37. See, for instance, Lindberg and Scheingold, Europe's Would-be Polity. For a recent summary of the literature, see Robert O. Keohane and Stanley Hoffmann, eds., The New European Community, Decisionmaking, and Institutional Change (Boulder, Colo.: Westview, 1991). 
the veto right invited sharp criticism by realist thinkers ${ }^{38}$ and sparked modifications to the explanations supplied by functionalists. ${ }^{39}$ However, in the words of Fritz Scharpf, theoretical developments since the 1960s have only increased the "several varieties of ad hoc explanations." 40

Although scholars have once again become interested in regional integration since the mid-1980s, most studies focus on either the achievements or setbacks in this form of cooperation. No consensus has emerged on why the most significant developments occurred. ${ }^{41}$ The literature addressing the Internal Market Program and the SEA offers explanations that disagree on the role of supranational institutions and transnational interest groups. According to a more holistic understanding of integration set forth by Wayne Sandholtz and John Zysman, Europe's revival is due to "a complex web of intergovernmental bargains and accommodations among various national business elites." ${ }^{22}$ While not completely denying the importance of government strategies, these authors stress the impact of changes in the international economic environment. In contrast, Moravcsik interpreted the SEA as the result of "intergovernmental institutionalism." 43 By describing the interests of states as the "primary source of integration," he rejected the claim that "supranational" variables (i.e., the momentum of European institutions and/or the activity of transnational interest groups or international leadership) account for "the timing, content and process of negotiating the SEA." 44 David Cameron prudently concludes that "the 1992 initiative was the product of a complex interaction among several economic, institutional, and political factors, some of which were integrationist and other intergovernmental." 45

A similar debate also appears to be emerging over the most recent development in the European integration process, the Maastricht agreement. According to one point of view, this treaty is to a large extent a timely reaction to systemic constraints, in particular the loss of autonomy following increased global integration of financial markets. ${ }^{46} \mathrm{~A}$ conflicting hypothesis postulates

38. Stanley Hoffmann, "Obstinate or Obsolete? The Fate of the Nation-State and the Case of Western Europe," Daedalus 95 (Summer 1966), pp. 862-915.

39. Lindberg and Scheingold, Europe's Would-be Polity.

40. Fritz W. Scharpf, "The Joint-Decision Trap: Lessons from German Federalism and European Integration," Public Administration 66 (Fall 1988), pp. 239-78.

41. Ernst B. Haas's "Turbulent Fields and the Theory of Regional Integration," International Organization 30 (Spring 1976), pp. 173-212, marked the end of the first wave of integration research. See also Friedrich Kratochwil and John Gerard Ruggie, "International Organization: A State of the Art on an Art of the State," International Organization 40 (Autumn 1986), pp. 753-75.

42. Sandholtz and Zysman, "1992," p. 127.

43. Moravcsik, "Negotiating the Single European Act."

44. See ibid., pp. 75 and 67 , respectively.

45. David R. Cameron, "The 1992 Initiative: Causes and Consequences," in Alberta M. Sbragia, ed., Euro-politics, Institutions, and Policymaking in the "New" European Community (Washington, D.C.: Brookings Institution, 1992), p. 65.

46. David M. Andrews, "Germany, Maastricht, and EMU: The Limits of Integration Theory," paper presented at the annual convention of the International Studies Association, Atlanta, Ga., 31 March-4 April 1992. See also Wayne Sandholtz, "Choosing Union: Monetary Politics and Maastricht," International Organization 47 (Winter 1993), pp. 1-39. 
that spillover effects and political leadership were central moving forces behind this achievement. ${ }^{47}$

Since the history of integration leading up to today's European Union is characterized by a stop-and-go pattern, case study research focusing exclusively on either progress or setbacks addresses only half of the story. A more accurate integration theory must allow for both successes and failures. We propose models that help to elucidate both types of outcomes. Before presenting our limited information games, it is useful to provide an inventory of alternative approaches that also promise to account for the variance between the realist and liberal extremes. While these contributions undoubtedly are of great value in accounting for regional integration processes, they fall short of a complete explanation of the stop-and-go pattern in European integration.

There are, roughly speaking, four alternative explanations to account for the shifts in European integration. First, it is possible to assume that a new actor might be powerful enough to enact a new policy. This interpretation links the shifts in interstate cooperation to events such as government changes, which are largely exogenous to the integration process. ${ }^{48}$ (A variant of this explanation emphasizes the unexpected reactions by domestic constituents once the summit is over. The first Danish referendum on the Maastricht treaty showed that ratification increasingly influences the course of European integration..$^{49}$ ) However, this article tries to explore whether or not endogenous factors are also at work. In other words, we attempt to show that some characteristics of the summitry itself contribute to the stop-and-go logic.

A second way of explaining change attributes different outcomes to variations in the economic environment. An expanding economy and equally distributed growth would thus make an agreement easier while economic turmoil would have severe repercussions for the integration process. In contradiction to this theory, some setbacks - such as the failed enlargements of the 1960s-have occurred during periods of economic success: integration crises are not necessarily linked to growing economic disparities or different growth rates..$^{50}$

A third research area focuses on possible endogenous factors and relies on the concept of iterated games. Various game-theoretic Folk theorems ${ }^{51}$ and

47. Finn Laursen, "Toward European Political Union: An Analysis of the Intergovernmental Conference on Political Union," paper presented at the annual convention of the International Studies Association, Atlanta, Ga., 31 March-4 April 1992.

48. Garrett, "International Cooperation and Institutional Choice."

49. See Gerald Schneider, "Getting Closer at Different Speeds: Strategic Interaction in Widening European Integration," in Pierre Allan and Christian Schmidt, eds., Game Theory and International Relations (Cheltenham, England: Edward Elgar, 1994), pp. 125-55; and Gerald Schneider and Patricia A. Weitsman, "The Punishment Trap: Integration Referendums as Popularity Contests," typescript, Graduate Institute of International Studies, Geneva.

50. William Wallace, "Less than a Federation, More than a Regime: The Community as a Political System," in Helen Wallace, William Wallace, and Carol Webb, eds., Policy Making in the European Community (Chichester, England: John Wiley and Sons, 1977), pp. 403-36.

51. See, for instance, Robert Aumann, "Survey of Repeated Games," in Robert Aumann, ed., 
especially Robert Axelrod's The Evolution of Cooperation have shown that the infinite repetition of such well-known games like the prisoners' dilemma can include both cooperative and conflictual outcomes. ${ }^{52}$ Empirical illustrations to support these models refer to situations like the cold war, where the two antagonistic powers do not know the result of their interactions in a more or less stable strategic context. This view contrasts with the reality of the meetings of the European Council, which were held in a more fluid surrounding. Since domestic concerns often influence decision makers on such occasions, it seems appropriate to model these summits as events governed by a shortened time horizon rather than as an infinite succession of similarly structured interactions.

The fourth possibility is that the actors themselves develop new interests through learning and adaptation. This hypothesis is very important in liberal thinking. Drawing on Haas's work, Sandholtz links learning to problems requiring coordinated action: "Policy preferences change as decision-makers acquire increased technical understanding of the problem." 53 Duncan Snidal's recent studies on game transformations offer a framework that could be used to analyze learning. ${ }^{54}$ Although these models do not directly address the disputed issue of how the game itself alters preferences, they show the importance of variations in payoff orders. ${ }^{55}$ Cooperative outcomes are only impossible if states find themselves in a prisoners' dilemma or if they care very much about the gains of the other side. Although this modeling approach may be very useful for refuting some orthodoxies of neorealism, it does not fully capture the dynamics of EC summitry since it does not explicitly address the intricacies of strategic bargaining. ${ }^{56}$

Essays in Game Theory and Mathematical Economics in Honor of Oscar Morgenstern (Mannheim, Germany: Bibliographisches Institut, 1981), pp. 11-42; Drew Fudenberg and Eric Maskin, "The Folk Theorem in Repeated Games with Discounting and with Incomplete Information," Econometrica 54 (May 1986), pp. 533-64; or Eric Van Damme, Stability and Perfection of Nash Equilibria (Heidelberg: Springer-Verlag, 1987).

52. Robert Axelrod, The Evolution of Cooperation (New York: Basic Books, 1984). See also Robert Axelrod and Robert O. Keohane, "Achieving Cooperation Under Anarchy: Strategies and Institutions," in Kenneth A. Oye, ed., Cooperation Under Anarchy (Princeton, N.J.: Princeton University Press, 1986), pp. 226-54.

53. Wayne Sandholtz, High-tech Europe: The Politics of International Cooperation (Berkeley: University of California Press, 1992), p. 30.

54. See Duncan Snidal, "Relative Gains and the Pattern of International Cooperation," American Political Science Review 85 (September 1991), pp. 701-26; and Duncan Snidal, "International Cooperation Among Relative Gain Maximizers," International Studies Quarterly 35 (December 1991), pp. 387-402.

55. For an example of the viewpoint that there is no such thing as self-induced changes of taste, see George J. Stigler and Gary S. Becker, "De Gustibus Non Est Disputandum," American Economic Review 67 (March 1977), pp. 76-90. See also Carl Christian von Weizäcker, "Notes on Endogenous Change of Tastes," Journal of Economic Theory 3 (December 1971), pp. 345-72. Summaries of this literature include Jon Elster, Ulysses and the Sirens: Studies in Rationality and Irrationality (Cambridge, Mass.: Cambridge University Press, 1979); and Gerald Schneider, Time, Planning, and Policymaking: An Evaluation of a Complex Relationship (Bern: Peter Lang, 1991).

56. For the original argument on relative gain-seeking, see Waltz, Theory of International Politics. For a game-theoretic formulation of the concept, see Joseph M. Grieco, Cooperation Among 
Our argument about the role of strategic threats naturally hinges upon the presence of exploitable information asymmetries. It may seem that the manipulation of uncertainty plays a less central role in negotiations among Western democracies outside the security issue-area. However, our assumption that private information comes into play in negotiations over nonmilitary matters is based on two observations: first, if the actors were able to foresee the bargaining outcome, there would be no need to engage in cumbersome negotiations in the first place. For example, the case of the renegotiations about the entry terms for Britain cited earlier shows that Chancellor Schmidt was not sure whether Prime Minister Wilson's exit threat was credible or not. This uncertainty forced actors into the bargaining process. Second, the home government normally enjoys an informational advantage because of its control of domestic politics; it does not have to reveal how it will influence public attitudes toward the international treaty if a referendum is required. In representative democracies, policymakers can also keep quiet about future side-payments with which they intend to garner the support of skeptical legislators. This second argument shows that informational asymmetries are largely due to power asymmetries. ${ }^{57}$ The concept of two-level games recently has facilitated the study of domestically determined differences in bargaining strength in a more rigorous fashion..$^{58}$

This is not to say that leaders are always perfectly informed about their own polities. Summarizing the findings of a major empirical study, Peter Evans finds that leaders "did try to strategically misrepresent their own polities, but not as often as expected, and with much less success." ${ }^{59}$ Moravcsik goes even further in cautioning that "among modern information-rich democracies, it is extremely difficult for negotiators to mask their true domestic win-set, even in a sensitive area of national security like weapons procurement." ${ }^{60}$ On the other hand, there is a rich literature documenting a similar use of unequally distributed information even within Western democracies. The exploitation of

Nations: Europe, America, and Non-tariff Barriers of Trade (Ithaca, N.Y.: Cornell University Press, $1990)$.

57. This point has also been made by Knight, Institutions and Social Conflict, pp. 142-45.

58. For the original argument, see Robert D. Putnam, "Diplomacy and Domestic Politics: The Logic of Two-level Games," International Organization 42 (Summer 1988), pp. 427-60. Critical extensions are presented in Fredrick W. Mayer, "Managing Domestic Differences in International Negotiations: The Strategic Use of Internal Side-payments," International Organization 46 (Autumn 1992), pp. 793-818; and Keisuke Iida, "When and How Do Domestic Constraints Matter? Two-level Games with Uncertainty," Joumal of Conflict Resolution 37 (September 1993), pp. 403-26.

59. Peter B. Evans, "Building an Integrative Approach to International and Domestic Politics: Reflections and Projections," in Peter B. Evans, Harold K. Jacobson, and Robert D. Putnam, Double-edged Diplomacy: International Bargaining and Domestic Politics (Berkeley: University of California Press, 1993), pp. 397-430; the quotation is drawn from p. 409.

60. Andrew Moravcsik, "Armaments Among Allies: European Weapons Collaboration, 19751985," in Evans, Jacobson, and Putnam, Double-edged Diplomacy, pp. 128-67; the quotation is drawn from p. 159. 
private information by legislative committees constitutes one particularly well-studied example. ${ }^{61}$

On balance, we conclude that the issue of incomplete information bargaining remains an open empirical question. Though we do not aspire to settle this debate, we hope that the cases drawn from European integration will shed additional light on the frequency and feasibility of information-based political strategies. As Keohane writes: "The significance of asymmetrical information and quality uncertainty in theories of market failure ... calls attention to the importance not only of international regimes but also variations in the degree of closure of different states' decisionmaking processes." 62

\section{The laggard against the rest}

\section{The exit game}

One obstacle to smoother increases in EC integration comprises threats by a state with minimalist preferences to exit from the community. To return to the first example, Prime Minister Wilson threatened to withdraw from the EC to obtain better terms for Britain in negotiations with more integration-friendly members. To see why an exit threat must lead to minimal agreements, negotiation stalemate, or actual exits, consider our first model, which we term the "exit game." This model assumes two players, which is an accurate representation of EC bargaining at the level of the European Council as long as unanimous approval is required to increase integration. Furthermore, in accordance with functionalist theory, the model assumes that both sides prefer to increase integration. We postulate, however, that they disagree as to the treaty's target level. In our notation, the laggard favors a more modest increase (the Less treaty), while the integrationist prefers a more ambitious project (the More treaty). Because the exit game involves uncertainty, the integrationist is unsure whether it is encountering a strong laggard who can credibly threaten to exit or a weak laggard without credibility.

Figure 1 illustrates the players' preferences graphically. The laggard's and the integrationist's utility functions, denoted $U_{1}$ and $U_{2}$, respectively, vary with the treaty's integration level. The main difference between the two curves is that the laggard's preferred outcome is less ambitious than the integrationist's. This implies that the laggard receives less from the More treaty (payoff $m_{1}$ ) than from the Less treaty (payoff $l_{1}$ ); that is, $l_{1}<m_{1}$. The integrationist's preferences are reversed $\left(l_{2}>m_{2}\right)$. The utility functions reflect the two governments' domestic support. Popular governments have flat curves since they are less sensitive to summits' outcome than less popular governments. The payoff differences $m_{1}-l_{1}$ and $m_{2}-l_{2}$ measure governments' sensitivity.

In addition to the two treaties, there are outside options. The laggard's strength influences how it views the consequences of an exit. After it executes

61. See, for example, Keith Krehbiel, Information and Legislative Organization.

62. Keohane, After Hegemony, p. 94. 


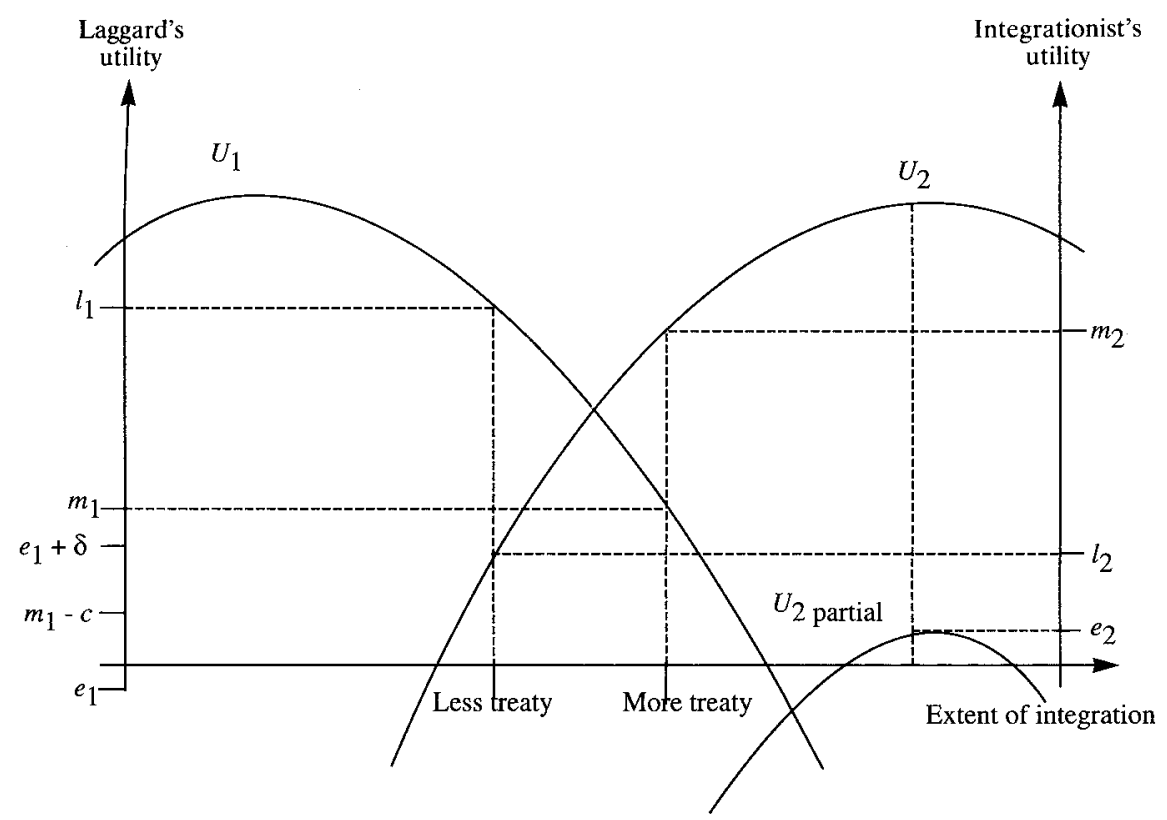

FIG URE 1. Deciding about more or less integration with exit options, where $U_{I}=$ the laggard's utility function; $U_{2}=$ the integrationist's utility function; $U_{\text {parial }}=$ the integrationist's utility function for a treaty without the laggard; $e_{1}=$ the laggard's exit payoff; $e_{2}=$ the integrationist's exclusion payoff; $m_{1}$ and $m_{2}=$ the laggard's and the integrationist's respective utility derived from a More treaty; $l_{1}$ and $l_{2}=$ the laggard's and the integrationist's respective utility derived from a Less treaty; $\delta=$ the strong laggard's offsetting gain after executing its exit threat; and $c=$ audience costs for backing down from the exit threat

its threat, the weak laggard receives the exit payoff $e_{1}$. By contrast, the strong laggard evaluates this outcome more positively and obtains $e_{1}$ plus an offsetting gain $\delta$. However, the obstructionist member of the organization still considers this payoff inferior to both treaties. To make the exit threat credible, the laggard needs to convince its opponent that backing down is too costly for itself. The obstructionist can achieve this by committing itself domestically to the preferred Less treaty. Backing down from this commitment would incur a domestic "audience cost" $c$ to the laggard, yielding the payoff $m_{1}-c$ which may or may not be worse than exit. ${ }^{63}$ Due to the strong laggard's tougher preferences $\left(e_{1}+\delta>m_{1}-c\right)$, it has a credible threat whereas its weaker counterpart does not $\left(m_{1}-c>e_{1}\right)$.

The functionalist assumption of integration-friendliness implies that the laggard would rather accept any treaty than exit. The exception to this rule is the strong laggard's reluctance to lose face domestically. On a theoretical level, 


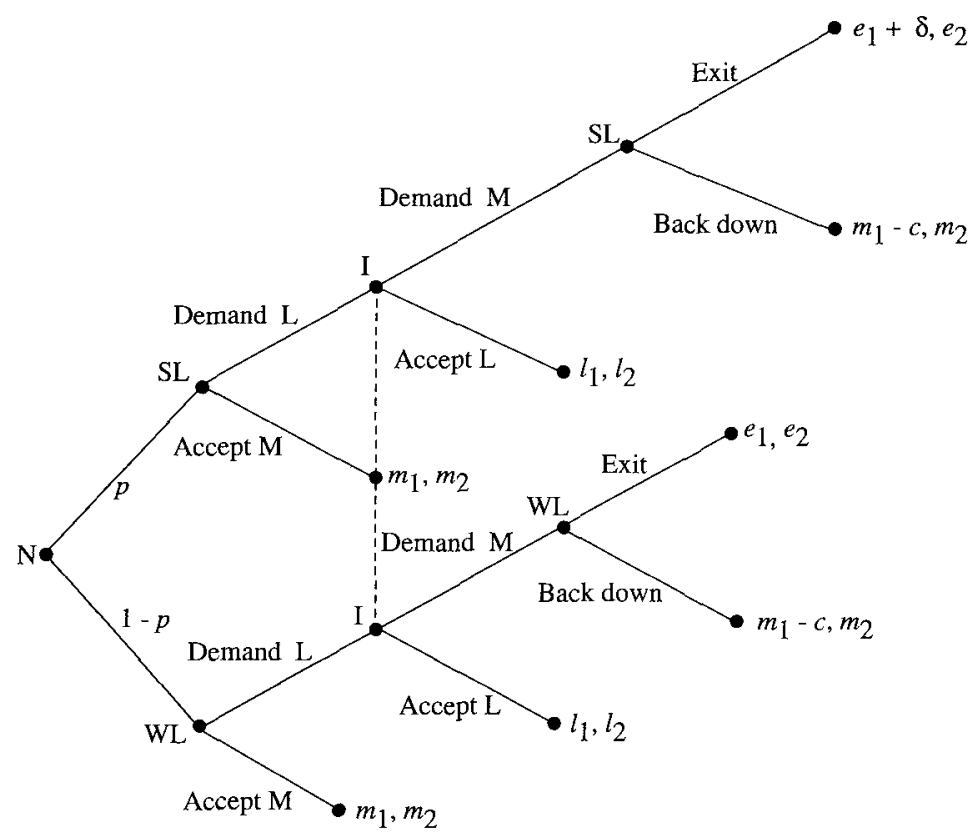

FIGURE 2. The exit game, where $N=$ Nature; $S L=$ strong laggard; $W L=$ weak laggard; $I=$ integrationist; $p=I$ 's prior belief of encountering a strong laggard; $L=$ Less treaty; and $M=$ More treaty (for definitions of other variables, see Figure 1)

this exception corresponds to the realist preoccupation with credibility. Like the laggard, the integrationist prefers both treaties to the former government's execution of the exit threat (payoff $e_{2}$ ). This means that the integrationist can never credibly threaten to exclude the laggard from an agreement $\left(e_{2}<l_{2}<\right.$ $m_{2}$ ). This preference is illustrated by shifting the integrationist's utility curve downward (compare $U_{2 \text { partial }}$, the utility obtained for a partial integration treaty without the laggard member).

To summarize, we assume the following preference orders.

Assumption 1. $e_{1}<m_{1}-c<e_{1}+\delta<m_{1}<l_{1}$

AsSumption 2. $e_{2}<l_{2}<m_{2}$

Incomplete information game theory offers an elegant way to model uncertainty. ${ }^{64}$ Figure 2 formalizes the strategic situation as a game tree with two main branches. We let a fictive player, Nature (labeled $\mathrm{N}$ in the figure) make

64. We employ the Harsanyi transformation to study this interaction as a situation of incomplete information. For an introduction to this technique, see Eric Rasmussen, Games and Information (Oxford: Basil Blackwell, 1990), pp. 54-60. 
the first move. If Nature chooses the upper branch, the laggard is strong (SL); otherwise, the laggard is weak (WL). Lacking information about Nature's move, the integrationist government (I) does not know which type of laggard it is playing against (thus, the dashed line connecting the two branches). The integrationist, however, observes the laggard's first move and may use this information to deduce the latter player's type. In this first move, the laggard can either immediately accept the More treaty (Accept M) or demand the Less treaty (Demand $\mathrm{L}$ ). If it demands the Less treaty, the integrationist responds by either accepting the laggard's offer (Accept L) or insisting on the More treaty (Demand M). In the event that the integrationist rejects the Less treaty, the laggard confronts a trade-off between losing face (Back down) or leaving the organization (Exit). Given assumption 1, it is clear that the strong laggard exits and the weak one gives in.

If there were no information asymmetry-if each player had complete information about the opponent's preferences-then the weak laggard would never attempt to bluff, and the two would always reach agreement on one or the other treaty. In other words, the liberal interpretation of political cooperation would be accurate in a world of certainty, since the Pareto-inferior exit option would never materialize. Proposition 1 summarizes this case more formally. ${ }^{65}$

PROPOSITION 1. Under complete information, the exit game has two integration equilibria. Equilibrium 1: If the integrationist is certain to encounter a weak laggard $(p=0)$, the negotiations result in the More treaty. Equilibrium 2: If the integrationist is certain to encounter a strong laggard $(p=1)$, the negotiations result in a Less treaty.

The proposition shows that, in the case of complete information, integration develops according to the functionalist account. If both sides intend to intensify their formal links, they can always reach an agreement, be it an ambitious More treaty or a humble Less treaty. The summitry negotiations are always efficient because the weak laggard never attempts to bluff. The strong laggard, by contrast, can successfully make an "irrevocable commitment" and squeeze the range of outcomes down to the Less treaty. This result is equivalent with Thomas Schelling's finding that constraints, or "the power to bind oneself," are an important source of bargaining power. ${ }^{66}$

Once we drop the certainty assumption, integration bargaining becomes much more complex. Going back to the full game specification, let us assume that the laggard has private information about its own preferences. ${ }^{67}$ The integrationist does thus not know whether it is dealing with a strong type or a

65. For a technical statement and proofs of all propositions, please see the appendix.

66. Thomas C. Schelling, The Strategy of Conflict (Cambridge, Mass.: Harvard University Press, 1960), pp. 21-52.

67. This simplifying assumption could be relaxed by introducing double-sided incomplete information. It is likely that similar results hold for this more general case. 
weak type. This kind of asymmetry opens the door for bluffs and forces the strong laggard to distinguish itself from its weak counterpart by issuing the exit threat.

If the integrationist thinks it is unlikely to face the strong laggard, it will sometimes call the weak laggard's bluff. But the insistence on the More treaty may also provoke an exit in the case that the laggard happens to be strong. Thus, up to a certain point, the integrationist will find it worthwhile to engage in risky bargaining. If this player is more confident that it is encountering a tough opponent, however, it will immediately give in and accept the Less treaty. The second proposition reports on these results.

PROPOSITION 2. Under incomplete information, the exit game has two major equilibria. Equilibrium 1: Up to a certain threshold belief $p_{0}=\left(m_{2}-l_{2}\right) /\left(m_{2}-e_{2}\right)$, the strong laggard always demands the Less treaty, which is sometimes accepted. This implies either exit or the Less treaty. The weak laggard, however, randomizes the first move between accepting the More treaty and demanding the Less treaty. In the latter case, the integrationist also randomizes its strategy, producing the Less treaty or the backing down outcome. Equilibrium 2: Beyond the threshold belief $p_{0}$, both the weak and the strong laggard always demand the Less treaty, which is immediately accepted by the integrationist.

This second proposition establishes that characteristics of the negotiation process itself contribute to the stop-and-go pattern in European integration. Our endogenous explanation of the change in the direction of political cooperation casts doubt on the liberal hypothesis that reduces integration to a coordination problem. However, the structural realist view that setbacks are the norm of regional integration is not justified either. Cooperation can evolve, but it is not a necessary development. The first game particularly shows that backlashes are possible despite all governments' desire to further the integration process. Exits take place when the integrationist misperceives the identity of the laggard. The integrationist's insistence on the More treaty forces the strong laggard to leave the organization. This mistake, which occurs only in the first equilibrium, produces a Pareto-inferior outcome. The second proposition also reveals that bluffing constitutes a salient aspect of integration negotiations under uncertainty. Traditional integration theory ignores such strategic manipulations.

We can use the deductive framework of the exit game to isolate the impact of key variables. Because it is the most interesting case, we focus on the first equilibrium of proposition $2 .^{68}$ Table 2 displays how changes in the laggard's signaling cost and domestic sensitivity as well as the integrationist's preference for the laggard's exit affect the likelihood of the different outcomes. ${ }^{69}$ Examples from the most crucial summit meetings illustrate our deductions.

68. Such a deduction of hypotheses is not applicable to the other equilibria of the exit game, since the outcome of each is unique.

69. The comparative statics results are derived by partially differentiating the outcome probabilities with respect to each parameter. See the appendix for details. 
TABLE 2. The effect of key parameters on the likelihood of the outcomes of the exit game ${ }^{\mathrm{a}}$

\begin{tabular}{lccc}
\hline \multicolumn{1}{c}{ Outcome } & $\begin{array}{c}\text { Laggard's } \\
\text { signaling costs }(c)\end{array}$ & $\begin{array}{c}\text { Laggard's sensitivity } \\
\text { to popularity }\left(l_{l}-m_{I}\right)\end{array}$ & $\begin{array}{c}\text { Integrationist's } \\
\text { exclusion payoff }\left(e_{2}\right)\end{array}$ \\
\hline More treaty & 0 & 0 & + \\
Back down & - & + & - \\
Less treaty & + & - & - \\
Exit & - & + & 0 \\
\hline
\end{tabular}

${ }^{\text {a } A}$ plus sign indicates a positive effect; a minus sign, a negative effect; and zero, no effect.

The different hypotheses are not tested quantitatively; such an endeavor would most likely lead to unreliable results, given the difficulties in measuring some of our concepts. In other words, this article is geared toward theory development rather than extensive testing of existing theories. ${ }^{70}$

As expected, the likelihood of an exit diminishes with increasing signaling costs $c$. Hence, integration in the form of the More treaty or the Less treaty outcomes becomes more likely when the laggard is able to commit itself strongly to the Less treaty. Prime Minister Thatcher was willing to pay these costs and to take the risk of isolating Britain internationally. Lord Carrington, Thatcher's Foreign Minister, writes retrospectively: "she had a strong-and entirely justified-feeling that Britain was the victim of deplorable inequity; and she was not temperamentally averse from showing the British people at home that when it came to outfacing foreigners she was in the first league." 71

The comparative statics show that it always pays the integrationist to convince the laggard that the integrationist's "outside option" is highly attractive. If the integrationist is able to raise its payoff $e_{2}$ for excluding the laggard, the More treaty becomes more probable at the expense of the Less treaty. To give an example for the tension between full and partial integration, France and Germany managed to convince Prime Minister James Callaghan that their payoff for excluding Britain from the exchange rate mechanism of the EMS was very high. Knowing this, Callaghan could not block France and Germany from striking their own deal. Commenting upon the negotiations, he writes in his memoirs that "there seemed little doubt that France and Germany would go ahead even if Britain did not join and their joint decision would almost automatically bring Belgium, Holland and Luxembourg into the scheme."72 Callaghan's negotiating position was weakened further by Ireland's decision to participate fully in the monetary regime. Giscard d'Estaing comments that

70. A similar modeling approach has been outlined by Morris Fiorina, "Formal Models in Political Science," American Journal of Political Science 19 (February 1975), pp. 133-59.

71. Lord Carrington, Reflect on Things Past (London: Collins, 1988), p. 319.

72. James Callaghan, Time and Chance (London: Collins, 1987), pp. 492-93. 
Callaghan's face hardened into "obstinacy" after the Irish defection. ${ }^{73}$ British negotiators finally kept out of the exchange rate mechanism, thus assuring a "soft landing" of not being completely excluded from the EMS. ${ }^{74}$ President Giscard d'Estaing and Chancellor Schmidt also were successful in November 1979 when they tried to convince Prime Minister Thatcher to accept their counteroffer during the EC budget crisis. Christopher Tugendhat writes, "As the vehemence of her arguments increased, Schmidt at one point feigned sleep, and when she refused to give in, the French party's cars were drawn up outside with their engines revving in order to emphasize the take-it-or-leave-it nature of what was an offer." 75 British insistence was unsuccessful. Margaret Thatcher finally gave in and asked for only a temporal extension to "save her face."76 Nevertheless, this defeat did not prevent Prime Minister Thatcher from raising similar demands at subsequent summits.

Table 2 also demonstrates how the sensitivity to considerations of popularity influences the likelihood of different negotiation outcomes. The less popular a laggard, the more important is the separation between the two treaties. Change from the More treaty to the Less treaty is linked to a considerable utility gain for a government under domestic pressure. Since the utility function is steep, the difference $l_{1}-m_{1}$ is small for an administration in such a situation. According to the comparative static results, unpopular governments have to count on a less favorable outcome than stronger ones. In other words, the probability of the Less treaty being adopted decreases when the distance $l_{1}-m_{1}$ grows. By the same token, the undesirable outcomes (exit and back down) become more likely. This is most likely one reason why Prime Minister Thatcher had relatively little success with her opposition against monetary integration. The integrationist governments knew that her fierce course was largely determined by popularity considerations.

Another possibility is that the image of the "Iron Lady" lost credibility over time. A weak laggard can try to build a reputation for toughness if the situation does not change dramatically over time. Such behavior might increase the integrationist's prior belief $p$ of encountering a strong laggard. The weak laggard faces the trade-off between accepting the less desirable More treaty immediately and trying to improve the outcome by pushing for the Less treaty. However, it can only obtain that treaty at the risk of having the bluff called. As $p$ is tuned upward, the chances of obtaining the Less treaty are enhanced, but simultaneously the probability of being forced to back down increases. The strong laggard, by contrast, only is able to control the outcomes by changing the cost parameter.

73. Valery Giscard d'Estaing, Le Pouvoir et la vie (Power and life), vol. 1 (Paris: CIE Douze, 1988), p. 150.

74. Butler, Europe, p. 69.

75. Christopher Tugendhat, Making Sense of Europe (London: Viking, 1986), p. 121.

76. Valery Giscard d'Estaing, Le Pouvoir et la vie (Power and Life), vol. 2 (Paris: CIE Douze, 1991), p. 463. 


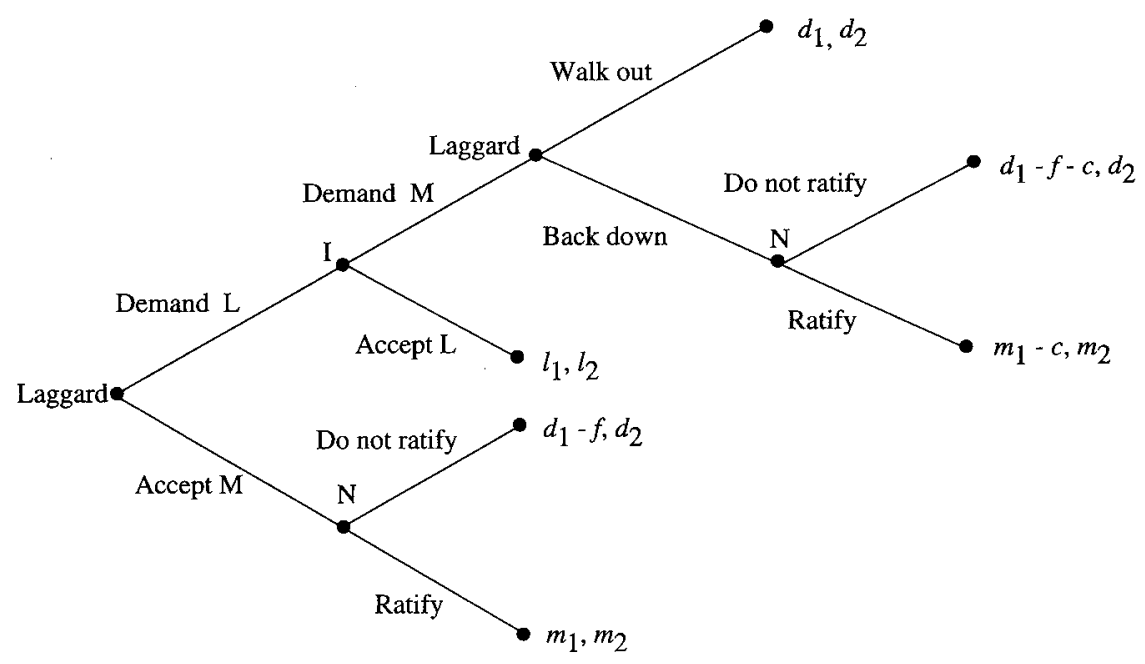

FIGURE 3. The ratification game, where $d_{1}$ and $d_{2}=$ respective negotiation payoffs (i.e., status quo) for the laggard and the integrationist and $f=$ the punishment costs for failed ratification (for definitions of other variables, see previous figures)

\section{Ratification and takeover threats}

Besides threatening to leave the organization, governments can use ratification and takeover threats. The consequences of these manipulations are not as drastic as those of an exit threat. In both the ratification and takeover games, the threat's execution results in negotiation failure. Since the laggard remains a member of the organization, the status quo prevails in these situations. This kind of stalemate becomes possible when a strong laggard is not satisfied with the counteroffer by the integrationist and responds with a walkout from a summit. This player is forced to execute its threat since neither the electorate (ratification game) nor the intraparty opposition (takeover game) would approve of a More treaty.

The ratification game. Figure 3 depicts the ratification game, in which the integrationist government is uncertain about the attitude of the domestic constituency in the laggard state. In contrast to Figure 2, Nature moves only after the players. This is more intuitive since the intergovernmental negotiations always precede the ratification. ${ }^{77}$ As in the exit game, the laggard's first choice is between accepting the More treaty and demanding the Less treaty. The integrationist decides whether to accept or reject this offer. If this second

77. The game can easily be transformed into one in which Nature moves first by using the Harsanyi transformation. See, for instance, Rasmussen, Games and Information, pp. 43-66. 
government insists on obtaining the More treaty, the laggard is forced either to walk out from the negotiations or to back down. The novel feature of this game is the ratification stage following any international agreement. Owing to our assumption that the domestic constituents always accept a Less treaty, we do not display the ratification move after the integrationist accepts this treaty. The other ratification moves, however, are depicted as chance moves.

We keep the same notation for the payoffs, except for the case of disagreement. In the ratification game, this contingency corresponds to the status quo rather than to exit from the organization. We denote the payoffs from this kind of negotiation deadlock as $d_{1}$ and $d_{2}$. The second important difference between the exit and ratification games is the increase in costs: if the strong laggard accepts a More treaty but cannot garner domestic support for it, the government receives a punishment $f$ for the failed ratification; and, if the laggard is forced to back down, cost $c$ of losing face is applied. Thus, in the event that the strong type subjects a More treaty to ratification, it could count on the payoffs $d_{1}-f-c$ and $d_{1}-f$, respectively.

The resulting preference orders are summarized in the following two assumptions:

Assumption 3. $d_{i}-f-c<d_{l}-f<d_{l}<m_{l}-c<m_{1}<l_{l}$

ASSUMPTION 4. $d_{2}<l_{2}<m_{2}$

Under complete information, the effects of a ratification threat correspond to the implications of an exit threat. Integration negotiations thus follow the functionalist prediction, with the strong laggard always obtaining the Less treaty and the weak one immediately succumbing to the More treaty. The suboptimal outcome of a walkout from negotiation never occurs unless there is uncertainty about the attitude of the domestic constituents in the laggard's country. The resulting deadlock situations are very common in the history of the EC. Prime Minister Wilson successfully used a ratification threat in combination with an exit threat as the Labour government subjected British membership to a popular referendum. On the eve of the Paris summit in December 1974, he said: "If renegotiations do not succeed, we shall not regard the treaty obligations as binding upon us. We shall then put to the British people the reasons why we find the new terms unacceptable, and consult them on the advisability of negotiating our withdrawal from the Communities." 78

Both Ireland and Denmark possibly could benefit by employing referendum threats. The Irish constitution requires a referendum on constitutional amendments such as the SEA and the Maastricht treaty. The Danish referendum tradition and the lack of parliamentary support contributed to its rather timid bargaining stance during SEA negotiations when the Conservative-led govern-

78. Harold Wilson, Final Term (London: Weidenfeld and Nicolson, 1979), p. 543. 


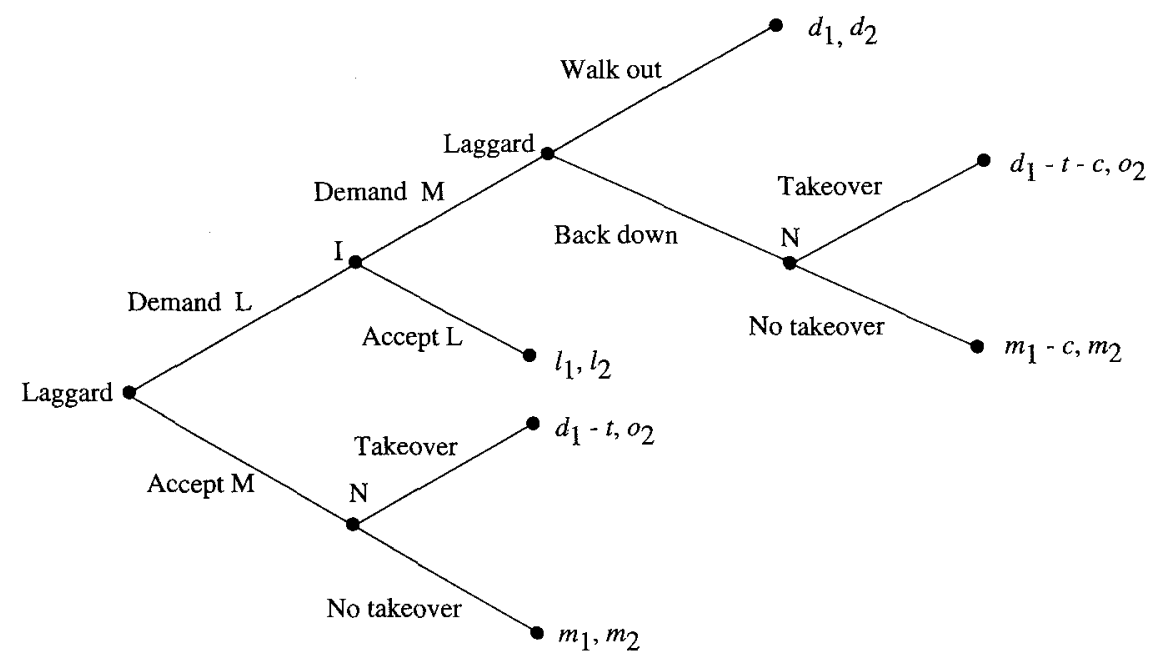

FIGURE 4. The takeover game, where $o_{2}=$ the integrationist's payoff from completion of a treaty with the laggard's former opposition and $t=$ takeover costs (for definitions of other variables, see previous figures)

ment opted for a position similar to that of Britain. ${ }^{79}$ As this unstable government coalition could not count on support from the dominant Social Democrats in the Folketing (National Parliament), it decided to hold a referendum on the SEA even though a popular vote was not constitutionally required. The fear of a second failure after the initial rejection of the Maastricht agreement contributed to the EC's generosity toward the small Scandinavian member during negotiations over possible opt-outs from the Maastricht treaty.

A more detailed analysis of the game shows that the punishment for a ratification failure $(f)$ does not influence the likelihood of the possible outcomes. However, the possibility of such penalties enables weak laggards to bluff and forces strong laggards to issue threats. There is ample evidence for our assumption that it is very costly to lose a ratification. The most significant example is Norway; the voters' rejection of European Economic Community membership in 1972 had dramatic ramifications, including the resignation of the government and the reshaping of party alliances.

The takeover game. A laggard may also employ takeover threats to reach a more favorable treaty. As depicted in Figure 4, it can demand the Less treaty by threatening that the More treaty would provoke takeover by a less-integrationminded domestic opposition. If such a takeover happens, the integrationist could expect the payoff $o_{2}$ for the conclusion of the treaty with the opposition.

79. Garrett, "International Cooperation and Institutional Choice," p. 543. 
In contrast to the ratification game, the strong laggard's acceptance of the More treaty incurs takeover cost $t$. This punishment can be measured in terms of the popularity losses suffered by the resigning government. The preference assumptions are as follows:

Assumption 5. $d_{1}-t-c<d_{1}-t<d_{1}<m_{1}-c<m_{l}<l_{l}$

AsSUMPTION 6. $d_{2}<o_{2}<l_{2}<m_{2}$ or $o_{2}<d_{2}<l_{2}<m_{2}$

Under complete information, the strong laggard again obtains a Less treaty, while the weak laggard acquiesces to the More treaty. The strong laggard could furthermore walk out from the negotiations if the integrationist erroneously refused to yield the Less treaty. The reasons for a bargaining breakdown differ from those in the ratification game. Here, the higher the payoff the integrationist attributes to a treaty with the opposition, the less likely the success of a bluff.

In the realm of the EU, British governments have been successful in exploiting intraparty opposition to gain international bargaining leverage. If the main opposition is a faction favoring further integration, takeover threats are not credible. Opposition by more integration-minded Conservative members of Parliament contributed to the relatively weak negotiation position of Prime Minister Thatcher for the SEA. Ironically, her stubbornness in integration matters finally forced her out of power. The laggard of the 1980s was brought down by a revolt led by her foreign secretary, Sir Geoffrey Howe, who protested Thatcher's opposition to monetary integration.

\section{Conclusion}

As demonstrated above, regional integration follows a much less predictable pattern than traditional realist or functionalist theories expect. Our explanation is not the only one to deviate from the determinism of those approaches. In contrast to other alternatives, however, our information-based argument accounts for the effects of strategic bargaining on the integration process. In particular, our models enhance our understanding of how uncertainty about domestic conditions can be exploited by leaders seeking to improve the terms of an integration agreement. The presence of information asymmetries opens the door for strategic manipulation involving threats and signals. In contrast to functionalist predictions, these moves may cause the integration process to stall despite a desire on the part of all actors to reach an agreement. This observation highlights interesting parallels to structurally similar situations. In international crises, for instance, nations go to war despite their preference for peace. ${ }^{80}$

80. See Powell, Nuclear Deterrence Theory; and Fearon, "Deterrence and the Spiral Model." 
According to our framework, the change of tide in political cooperation depends on three conditions: first, all members of an organization (like the EC) prefer some increase in integration. Second, they have to disagree about the extent of cooperation. Third, there must be an informational asymmetry between the negotiators. The stop-and-go logic will be a typical feature of European integration as long as both intergovernmentalism and unanimity characterize all major decisions. $^{81}$

Although we found suggestive evidence for the presence of private information, more systematic research is called for. Two related questions are central in this respect: first, under what conditions do information asymmetries arise outside the security realm? Second, how successful have leaders been in exploiting such contingencies? Attempts to answer these questions should not be limited to European integration but would benefit from a wider empirical focus including international negotiations in various issue-areas.

The main purpose of this article has been to solve an important puzzle with the help of some powerful analytic tools that, to our knowledge, have not been applied to regional integration theory before. This does not mean, however, that we believe incomplete information modeling to be a panacea. We must be cautious for several reasons. Our framework represents a simplification of reality along at least three dimensions. First, our models include only one-sided incomplete information. In a more realistic setting, the integrationist can profit from uncertainty by issuing threats to counter the bargaining tactics of the laggard. For instance, an integration-minded government might use exclusion tactics strategically to force a laggard to support an integration agreement. Second, along the temporal dimension, our model is limited to disconnected one-shot bargains. This allows us to analyze the impact of situational variables but not of reputation building. Fortunately, our models could be extended to capture this feature. For an analysis of the long-term dynamics, however, evolutionary approaches offer the most fruitful ground for theory building. ${ }^{82}$ Finally, our model fails to address the spatial dimension explicitly despite its centrality in regional integration. Important factors such as subsidiarity, sovereignty, nationalism, and immigration cannot be understood without reference to the territorial aspect of international politics. ${ }^{83}$

81. Under majority voting, political integration could become a smoother process than predicted by our theory. In particular, there will be fewer chances for laggards to stall the negotiations. Spatial models analyzing effects of qualified majority voting include George Tsebelis, "The Power of the European Parliament as a Conditional Agenda Setter," American Political Science Review, forthcoming; and Gerald Schneider, "The Limits of Self-Reform: Institution Building in the European Union," typescript, Graduate Institute of International Studies, Geneva.

82. For alternative formal approaches, see Michael T. Hannan and John Freeman, Organizational Ecology (Cambridge, Mass.: Harvard University Press, 1989); or Richard R. Nelson and Sidney G. Winter, An Evolutionary Theory of Economic Change (Cambridge, Mass.: Harvard University Press, 1982).

83. Such factors are analyzed in Michael Don Ward, ed., The New Geopolitics (Philadelphia: Gordon and Breach, 1992). 
Despite these limitations, we believe that our results can contribute to current theory of regional integration. Formal reasoning of this type can improve understanding of counterintuitive effects that may be hard to recognize with verbal analysis. Under the assumption of integrationist preferences, the functionalist expectation of further formal cooperation was only confirmed in a world of certainty. In the case of incomplete information, this prediction turned out to be overly optimistic. This result should alert students of international cooperation to the importance of strategic behavior in general and the possibility of the manipulation of uncertainty in particular.

\section{Appendix: the exit game}

This appendix presents the proofs of propositions 1 and 2. To facilitate the calculations, we denote the likelihood that the strong laggard chooses Demand $\mathrm{L}$ in the first move as $r$. The corresponding probability for the weak laggard is $s$. The parameter $q$ stands for the probability that the integrationist demands the More treaty. Finally, we call the posterior belief $p^{\prime}$. We will often refer to the strong laggard as player 1, its weak counterpart as player $\mathbf{1}^{\prime}$, and the integrationist as player 2 .

We derive the universally divine equilibria for the exit game. This solution concept is a refinement of the perfect Bayesian equilibrium (PBE). Under complete information, this latter equilibrium coincides with the simpler subgame perfect equilibrium (SPE). It is useful to note that a 4-tuple $\left(r, s, q, p^{\prime}\right)$ fully defines the equilibria:

LEMM A. We can reduce the game by excluding dominated strategies: (i) the strong laggard's threat is credible, i.e., the second move of this player is always Exit; (ii) the weak laggard's threat is incredible, i.e., the second move of this player is always Back down; and (iii) if s $>0$ then $r=1$ and $q \neq 1$.

Proof. The two first parts of the lemma follow directly from the definition of the types in assumption 1, because $U_{1}$ (Exit) $>U_{1}$ (Back down) and $U_{1^{\prime}}$ (Exit) $<U_{1^{\prime}}$ (Back down). We use these results to prove the last claim (iii). Suppose the contrary, $r<1$, which is the same as $U_{1}$ (Demand $\left.\mathrm{L}\right)=q\left(e_{1}+\delta\right)+(1-q) l_{1} \leq U_{1}$ (Accept $\left.\mathrm{M}\right)=m_{1}$. Rearranging yields $q \geq\left(l_{1}-m_{1}\right) /\left(l_{1}-e_{1}-\delta\right)$. By assumption $s>0$, so we must have $U_{1^{\prime}}($ Demand $\mathrm{L})=q\left(m_{1}-\mathrm{c}\right)+(1-q) l_{1} \geq \mathrm{U}_{1^{\prime}}($ Accept $\mathrm{M})=m_{1}$ or $q \leq\left(l_{1}-m_{1}\right) /$ $\left(\mathrm{l}_{1}-m_{1}+c\right)$. Combining the two inequalities produces

$$
\frac{l_{1}-m_{1}}{l_{1}-e_{1}-\delta} \leq q \leq \frac{l_{1}-m_{1}}{l_{1}-m_{1}+c} .
$$

After simplification we obtain $e_{1}+\delta \leq m_{1}-c$, which contradicts assumption 1 . Thus, for $s>0$, it must be that $r=1$. To see that $q \neq 1$, suppose the opposite, $q=1$. But if the integrationist always calls the bluff, the weak laggard would never advance beyond the first move because this step would lead to the inferior outcome $m_{1}-c$, rather than $m_{1}$, for accepting the More treaty immediately. In this case, $s=0$, which contradicts the initial claim iii of the lemma, that $s>0$. In other words, for $s>0$ we know that $q \neq 1$. 
Now we are ready to derive the equilibria for the complete information game, i.e., for both $p=0$ and $p=1$. Note that the certainty corresponds to being either in the upper or lower part of the game tree.

Proposition 1. Under complete information, the exit game has two SPEs. Equilibrium 1: If the integrationist is certain to encounter the weak laggard $(p=0)$, the latter always acquiesces, resulting in the More treaty $\left(s=0, q=1 ; p^{\prime}=0\right)$. Equilibrium 2: If the integrationist is certain to encounter the strong laggard $(p=1)$, the latter demands the Less treaty followed by the integrationist's acceptance of this treaty $\left(r=1 ; q=0 ; p^{\prime}=1\right)$.

We derive the SPEs by backward induction.

Proof of equilibrium 1. If the integrationist is certain to encounter the weak laggard (i.e., $p=0$ ), it will choose Demand $\mathrm{M}$, since this type always backs down $(q=1)$. In formal terms, $U_{2}$ (Demand $\left.\mathrm{M}\right)=m_{2}>U_{2}($ Accept $\mathrm{L})=l_{2}$. Consequently, the weak laggard prefers Accept $\mathrm{M}$ instead of pushing ahead with Demand $\mathrm{L}(s=0): U_{1^{\prime}}$ (Accept $\mathrm{M})=m_{1}>U_{1^{\prime}}\left(\right.$ Demand L) $=m_{1}-c$. Thus, we conclude that the outcome must be the More treaty.

Proof of equilibrium 2. By contrast, if player 2 knows that it is in the upper node in the information set $(p=1)$, it chooses to accept the Less treaty since by assumption $2, U_{2}$ (Accept L) $=l_{2}>U_{2}$ (Demand $\left.\mathrm{M}\right)=e_{2}$. This implies $q=0$. Anticipating this opportunity, the laggard opts for Demand $\mathrm{L}$ in the first move $\left(r=1\right.$ ), since $U_{1}$ (Accept $\mathrm{M})=m_{1}<U_{1}$ (Demand $\left.\mathrm{L}\right)=l_{1}$. In this case, the outcome is the Less treaty.

Having established the complete information equilibria, we turn to the uncertain case. To derive the outcomes in the second proposition, we employ a refinement of the PBE, namely, universal divinity. ${ }^{84}$

Proposition 2. Under incomplete information, the exit game has two major cases and one minor case. Equilibrium 1: If $0<p<p_{0}$, the $P B E$ is partly pooling, described by the behavior strategies $r, s$, and $q$ and the integrationist's posterior belief $p^{\prime}$ such that $r=1, s=$ $p\left(l_{2}-e_{2}\right) /(1-p)\left(m_{2}-l_{2}\right), q=\left(l_{1}-m_{1}\right) /\left(l_{1}-m_{1}+c\right)$, and $p^{\prime}=p_{0}=\left(m_{2}-l_{2}\right) /\left(m_{2}-\right.$ $\left.e_{2}\right)$. This equilibrium collapses under the knife-edge condition $p=p_{0}$. We thus find a pooling equilibrium, equilibrium $1^{\prime}$, such that $r=1, s=1,0 \leq q<\left(l_{1}-m_{1}\right) /\left(l_{1}-m_{1}+c\right)$, and $p^{\prime}=p=p_{0}$. Equilibrium 2: If $p_{0}<p<1$, we obtain another pooling equilibrium; hence, $r=1, s=1, q=0$, and $p^{\prime}=p$.

Proof. We prove the proposition by considering all candidate equilibria. This amounts to checking whether each strategy-belief combination $\left(r, s, q, p^{\prime}\right)$ satisfies the condition for a PBE. Given the strategies, the posterior belief $p^{\prime}$ must therefore obey Bayes's rule. The strategies must also be each others' best replies for a given belief.

It is convenient to study different values of $s$. First, suppose that the weak laggard randomizes its first move: $0<s<1$. Then, this player must be indifferent between Accept $M$ and Demand $L$ in the first move:

$$
U_{1^{\prime}}(\text { Demand } \mathrm{L})=q\left(m_{1}-c\right)+(l-q) l_{\mathrm{I}}=U_{1^{\prime}}(\text { Accept } \mathrm{M})=m_{1}
$$

84. Jeffrey Banks and Joel Sobel, "Equilibrium Selection in Signaling Games," Econometrica 55 (May 1987), pp. 890-904. 
Solving for $q$ yields

$$
q=\frac{l_{1}-m_{1}}{l_{1}-m_{1}+c}
$$

Since $0<q<1$ by assumption 1 , the integrationist also mixes its strategy. From claim (iii) of the lemma we know that $\mathbf{r}=1$, which fixes all the strategies. It remains to be proven whether the posterior belief $p^{\prime}$ is consistent. We already have shown that the integrationist uses a mixed strategy, so it must be that

$$
U_{2}(\text { Demand } \mathrm{M})=p^{\prime} e_{2}+\left(1-p^{\prime}\right) m_{2}=U_{2}(\text { Accept } \mathrm{L})=l_{2}
$$

Using this equation, we determine $p^{\prime}$ :

$$
p^{\prime}=p_{0}=\frac{m_{2}-l_{2}}{m_{2}-e_{2}}
$$

In PBE, Bayes's rule must hold, which gives us a second expression for $p^{\prime}$ :

$$
p^{\prime}=\frac{p r}{p r+(1-p) s}=\frac{p}{p+(1-p) s}
$$

Equations A2 and A3 allow us to extract an expression for $s$ :

$$
s=\frac{p}{l-p} \frac{l_{2}-e_{2}}{m_{2}-l_{2}} .
$$

We have already constrained $s$ to satisfy $0<s<1$. This inequality is equivalent to $0<$ $p<p_{0}$, which defines case 1 . Hence, we have found the first PBE.

Proceeding to the second case, we assume that $s=1$. As requirement iii of the lemma applies, we know that $r=1$. Since there is no behavioral difference between the two types in the first move, no updating takes place (that is, $p^{\prime}=p$ ). The equilibrium must be pooling under these conditions. Claim iii of the Lemma also shows that $q \neq 1$, reducing the integrationist's strategies to two possibilities: $0<q<1$ and $q=0$. In the former case, equation $\mathrm{A} 1$ holds, fixing $p=p^{\prime}=p_{0}$. This is nothing but the pooling equilibrium in the knife-edge equilibrium 1', separating equilibrium 1 from equilibrium 2 . The latter case $(q=0)$, however, implies that $U_{2}$ (Accept $\left.\mathrm{L}\right)>\mathrm{U}_{2}$ (Demand $\mathrm{M}$ ). This simplifies to $p_{0}<p=p^{\prime}<1$, thus setting the boundaries of the pooling equilibrium in case 2 .

We have as yet not analyzed the contingency $s=0$. Under this assumption, requirement iii of the lemma does not apply. As a consequence we need to consider all possible values of $r$. Suppose, first, that $r>0$. In this case, we can apply Bayes's rule to calculate the posterior belief $p^{\prime}=p r /[p r+(1-p) s]=p r / p r=1$. But if the integrationist is certain to be in the upper node of the information set, it will surely play Accept $\mathrm{L}$, or $q=0$. Anticipating this move, the weak laggard has an incentive to exploit the situation by playing Demand $\mathrm{L}$ since $l_{1}>m_{1}$. As this result contradicts the 
TABLE A1. Summary of the equilibria of propositions 1 and 2 (the exit game)

\begin{tabular}{|c|c|c|c|c|c|}
\hline \multirow[b]{2}{*}{$\begin{array}{l}\text { Prior } \\
\text { belief }\end{array}$} & \multirow[b]{2}{*}{$\begin{array}{l}\text { Complete } \\
\text { information } \\
\quad(p=0)\end{array}$} & \multicolumn{3}{|c|}{ Incomplete information } & \multirow[b]{2}{*}{$\begin{array}{l}\text { Complete } \\
\text { information } \\
\quad(p=1)\end{array}$} \\
\hline & & $\begin{array}{c}\text { Case 1 } \\
\left(0<p<p_{0}\right)\end{array}$ & $\begin{array}{c}\text { Case 1' } \\
\left(p=p_{0}\right)\end{array}$ & $\begin{array}{c}\text { Case 2 } \\
\left(p_{0}<p<1\right)\end{array}$ & \\
\hline$r$ & - & 1 & 1 & 1 & 1 \\
\hline$s$ & 0 & $\frac{p}{1-p} \frac{l_{2}-e_{2}}{m_{2}-l_{2}}$ & 1 & 1 & - \\
\hline$q$ & 1 & $\frac{l_{1}-m_{1}}{l_{1}-m_{1}+c}$ & $0 \leq q<\frac{l_{1}-m_{1}}{l_{1}-m_{1}+c}$ & 0 & 0 \\
\hline$p^{\prime}$ & 0 & $p_{0}=\frac{m_{2}-l_{2}}{m_{2}-e_{2}}$ & $p_{0}=\frac{m_{2}-l_{2}}{m_{2}-e_{2}}$ & $p$ & 1 \\
\hline $\operatorname{Pr}(M)$ & 1 & $1-\frac{p}{p_{0}}$ & 0 & 0 & 0 \\
\hline $\operatorname{Pr}\left(M^{\prime}\right)$ & 0 & $p \frac{l_{2}-e_{2}}{m_{2}-l_{2}} \frac{l_{1}-m_{1}}{l_{1}-m_{1}+c}$ & $\frac{l_{2}-e_{2}}{m_{2}-e_{2}} \frac{l_{1}-m_{1}}{l_{1}-m_{1}+c}$ & 0 & 0 \\
\hline $\operatorname{Pr}(L)$ & 0 & $\frac{p}{p_{0}} \frac{c}{l_{1}-m_{1}+c}$ & $\frac{c}{l_{1}-m_{1}+c}$ & 1 & 1 \\
\hline $\operatorname{Pr}(E)$ & 0 & $p \frac{l_{1}-m_{1}}{l_{1}-m_{1}+c}$ & $p_{0} \frac{l_{1}-m_{1}}{l_{1}-m_{1}+c}$ & 0 & 0 \\
\hline
\end{tabular}

assumption $s=0$, the combination cannot be a PBE. Only one possibility remains, namely, that $r=0$.

Finally, we need to consider the possibility that both $s=0$ and $r=0$. The problem with this strategy combination is that player 2's information set cannot be reached, excluding the use of Bayes's rule for the derivation of $p^{\prime}$. This case, however, can be discarded by constraining the out-of-equilibrium belief with the help of the universal divinity criterion or, more precisely, the weaker "D1 criterion." 85 This refinement requires that whenever the weak laggard weakly prefers to defect from the equilibrium, the strong laggard strictly prefers to deviate. If this holds, we know that the integrationist has to place zero belief on encountering the weak laggard, since the strong laggard is "more likely" to deviate from the equilibrium than the weak laggard. Formally, if for all $q$ such that $U_{1^{\prime}}$ (Accept $\left.\mathrm{M}\right) \leq U_{1^{\prime}}$ (Demand L), we have $U_{1}$ (Accept M) $<U_{1}$ (Demand L), then the D1 criterion implies $1-p^{\prime}=0$ or $p^{\prime}=1$. But we know that this condition holds, because $m_{1} \leq q\left(m_{1}-c\right)+(1-q) l_{1}$ always implies $m_{1}<q$ $\left(e_{1}+\delta\right)+(1-q) l_{1}$, by assumption 1 . Thus, it must be that $p^{\prime}=1$. However, from above 
we know that $p^{\prime}=1$ violates the assumption $s=0$. Consequently, the strategy combination $r=0, s=0$ can be ruled out by appealing to the D1 criterion. Obviously, this criterion also holds for all nonzero beliefs.

Having exhausted all strategy-belief combinations, we have proved that the equilibria of the proposition are not only PBE but also unique.

Some of the alternative equilibrium refinements are not restrictive enough to discard the out-of-equilibrium belief in the exit game. ${ }^{86}$ For example, the weaker intuitive criterion does not rule out the $r=s=0$ equilibrium, because there are best responses $q$ by the integrationist such that the weak laggard has an incentive to deviate from the equilibrium strategy (i.e., $s>0$ ). It should be noted that the idea of equilibrium refinements is a controversial subject in the theoretical literature. ${ }^{87}$

Table A1 presents a summary of the results for propositions 1 and 2. The lower part of the table also contains the probabilities of the outcomes for each equilibrium. The outcomes are denoted as follows. While $\operatorname{Pr}(M)$ represents the probability of the laggard's immediate acceptance of the More treaty, $\operatorname{Pr}\left(M^{\prime}\right)$ corresponds to the probability of the same outcome, but only after this actor has backed down. The likelihood of the two remaining outcomes is $\operatorname{Pr}(L)$ for the Less treaty and $\operatorname{Pr}(E)$ for exit.

The outcome probabilities are easily calculated as a product of the probability of the branches leading to each outcome:

$$
\begin{aligned}
& \operatorname{Pr}(M)=(1-p)(1-s)=(1-p)\left(1-\frac{p}{1-p} \frac{l_{2}-e_{2}}{m_{2}-l_{2}}\right)=1-p \frac{m_{2}-e_{2}}{m_{2}-l_{2}}=1-\frac{p}{p_{0}} \\
& \operatorname{Pr}\left(M^{\prime}\right)=(1-p) s q=p \frac{l_{2}-e_{2}}{m_{2}-l_{2}} \frac{l_{1}-m_{1}}{l_{1}-m_{1}+c} \\
& \operatorname{Pr}(L)=p(1-q)+(1-p) s(1-q)=[p+(1-p) s](1-q) \\
& \quad=p\left(1+\frac{l_{2}-e_{2}}{m_{2}-l_{2}}\right)\left(1-\frac{l_{1}-m_{1}}{l_{1}-m_{1}+c}\right)=p \frac{e_{2}-l_{2}}{l_{2}-m_{2}} \frac{c}{l_{1}-m_{1}+c}=\frac{p}{p_{0}} \frac{c}{l_{1}-m_{1}+c} \\
& \operatorname{Pr}(E)=p q=p \frac{l_{1}-m_{1}}{l_{1}-m_{1}+c}
\end{aligned}
$$

86. Drew Fudenberg and Jean Tirole, Game Theory (Cambridge, Mass.: MIT Press, 1991), chap. 11.

87. See Ken Binmore, Essays on the Foundation of Game Theory (Cambridge, Mass.: Basil Blackwell, 1990); and David M. Kreps, A Course in Microeconomic Theory (Princeton, N.J.: Princeton University Press, 1990), p. 437. 